\title{
Biocidal and Antinemic Properties of Aqueous Extracts of Ageratum and Coccinia Against Root-Knot Nematode, Meloidogyne Incognita In Vitro
}

\author{
Mohd Asif ${ }^{1 *}$, Moh Tariq, Amir Khan and Mansoor A. Siddiqui \\ Received: $14^{\text {th }}$ December 2016 / Accepted: $20^{\text {th }}$ January 2017
}

\begin{abstract}
Plants are the one of the glorious and fascinating source of natural biopesticides. The present investigation was carried out for pytochemical analysis and to assess the nematicidal and nematostatic potential of aqueous extract of some plant parts viz., Ageratum conyzoides and Coccinia grandis against hatching and nematicidal behavior of root-knot nematode, Meloidogyne incognita in vitro conditions. The second stage juveniles (J2) were exposed at 24, 48 and 72 hours in different concentration ( $S, S / 2, S / 10$, and $S / 100)$ of plant extracts. During in vitro condition inhibition of egg hatchability and $J_{2}$ juveniles' mortality varied according to the concentration of plant extract. The extract of Ageratum conyzoides leaves and stem exhibited highly promising mortality (98-100\%) after 72 hours of exposure periods while the plant extract of $C$. grandis leaves and fruit showed minimum mortality (56-60\%) after 24 hours of exposure periods. There was a gradual decrease in egghatching with an increase in the concentration of aqueous extract of plants. A. conyzoides leaves and stem extract elucidating most effectiveness in reducing egghatching and increase in mortality of $J_{2}$ juveniles of $M$. incognita. Concentration of the extract was directly proportional to the mortality of second stage juveniles and inversely proportional to the egghatching. Phytochemical analysis in various solvent of different polarity such as ethanol, methanol, acetone, chloroform, petroleum and water marked the impressive outcome of alkaloids, saponins, tannins, flavonoids, protein, amines, glycosides, carbohydrate, steroids, mucilage, gums, terpenoids and phlobatannins in the plant extracts. The aqueous extract of Ageratum conyzoides showed maximum egg inhibition and $J_{2}$ juvenile mortality due to the presence of phytoconstituents such as alkaloid, tannins, phenol, saponins, glycosides, flavonoids, carbohydrate, protein, mucilage/gum and phlobatannins while Coccinia grandis showed minimum egg inhibition and juvenile mortality.
\end{abstract}

Keywords: Plant extract, Egghatching, Juvenile mortality, phytochemical analysis.

\section{INTRODUCTION}

Plants are an important source of naturally occurring pesticides which may serve as safer alternatives for synthetic nematicides of which research in this area has increased manifolds (Ujvary, 2002). About three quarters of the World's population relies on plants and its extracts for health care (Premanathan et al., 2000; Gabhe et al., 2006). Plant extracts containing volatile compounds (Brown and Morra, 1997), especially essential oils, have been found to possess antimicrobial, insecticidal and nematicidal activity (Digrak, 1999; Okoko, et al., 1999). Flora of the nature is the reservoir of large number secondary metabolites viz., alkaloids, flavonoids, phenol etc to defend themselves against various diseases and pests. A numbers of plants which having nematicidal properties have been investigated. The application of extracts either enabled the plants to resist the nematode invasion or activated directly the defense mechanisms of plants (Mukhtar et al., 2013). 
Phytochemistry is concerned with the chemical study of these plant constituents (Evans, 2002). Phytochemicals have been recognized as the basis for global traditional herbal medicine (Lalitha and Jayanthi, 2012).

Plant parasitic nematodes and soil borne pathogen also attack a wide range of vegetables reducing its yield quality and quantity(Nchore et al., 2011), where Meloidogyne incognita was found constantly associated with the vegetable crops (Asif et al., 2016) and population of nematode was influenced by moisture, temperature, clay and silt percentage (Asif et al., 2015). The symptoms of root-knot nematode attack on crops include root galling, chlorosis, stunted growth and poor yields and sometimes over all crop failure were also observed. The estimated yearly crop loss due to root-knot nematode is $\$ 100$ billion worldwide (Oka et al., 2000). Estimated overall average annual yield loss on the world's major crops due to damage by plant parasitic nematodes is 12.3 $\%$ (Ravichandra, 2008). In India, a loss to the extent of Rs. 21,068.73 million in 24 different crops was estimated (Jain et al., 2007).

Nematodes are difficult to control because of their wide host range and high rate of reproduction, with females capable of producing up to thousand eggs / female and caused the serious yield losses on a wide range of crops (Natarajan et al., 2006). The rootknot nematode, Meloidogyne incognita were controlled through the use of cultural methods, chemical nematicides, crop rotation (Chitwood, 2002), resistant varieties and biocontrol agents (Mukhtar and Pervaz, 2003). The use of synthetic nematicides has been the most effective method for the management of plant-parasitic nematodes, but their high cost and hazardous effect on human health, environment and ground water contamination create a necessity to search new, cheap, eco-friendly and harmless methods of nematode control (Chitwood, 2003). Therefore, the use of plant extracts and phyto-products is gaining attention due to their availability, cost effectiveness, proven nature of specificity, no biodegradability, low toxicity and minimum residual toxicity in the ecosystem (Maji et al., 2005).

A number of organic components of plant origin, including oil-seed cakes, chopped plant parts and plant extracts have been used as nematode control agents (Akhtar and Alam, 1993; Tiyagi et al., 2009a; Parihar et al., 2012). Botanical extracts that contain alkaloids and flavonoids were found to have ovicidal property against Meloidogyne eggs (Adegbite, 2003). Aqueous leaf extract of extracts of Acyranthes aspera and Solanum xanthocarpum was found highly toxic and showed $100 \%$ inhibition in the egg hatching and juvenile mortality of Meloidogyne incognita (Asif et al., 2017). Similarly, aqueous extract of Datura stramonium was also found to be more effective on the second stage juveniles of M. javanica in tomato plants (Al-Saba et al., 2001). However, the effect of pesticide over use and misuse around the world has led to costly environmental pollution and disruption of the balance of nature (IITA, 2000).

In recent years, studies have shown the importance of natural nematicidal compounds in the plants themselves that have potential to suppress nematode populations (Pavaraj et al., 2010; Moosavi, 2012; Nelaballe and Mukkara, 2013; Muniasamy et al., 2010). Many botanical extracts have been found to contain phytochemicals such as alkaloids, tannins, saponins, flavonoids, diterpenes, glucosinolates, acetylenes and thinlys (Chitwood, 2002) which are effective against plant parasitic nematodes (Goswani and Vijayalakshmi, 1986; Adegbite, 2003). Hence the study was conducted with the aim of phytochemical screening of Ageratum conyzoides and Coccinia grandis and to characterize the main constituents responsible for the inhibition of egg hatching and second stage juvenile (J2) mortality of Meloidogyne incognita in vitro. 


\section{MATERIALS AND METHODS}

\section{Culture for the nematode inoculum}

Pure nematode culture was prepared in brinjal. Highly infected roots of brinjal (Solanum melongena L.) family- Solanaceae was uprooted gently so that eggmasses don't get detached from the root and washed in distilled water properly until whole of the soil debris get removed then placed in 15 mesh sieves ( 8 $\mathrm{cm}$ in diameter) having crossed layer of tissue and placed in petridishes having water just deep enough to contact the eggmasses which can favour the juvenile hatching.

\section{Preparation of extract}

Leaves stem and fruit of two different plants species viz., Ageratum conyzoides (FamilyAstraceae) and Coccinia grandis (FamilyCuccurbitaceae) were collected from Aligarh Muslim University campus, Near Allama Iqbal Hall, thoroughly washed and chopped. Chopped leaves $(25 \mathrm{~g})$ of each sample were soaked in $75 \mathrm{ml}$ distilled water and kept overnight. The preparation of extract was taken through the grinding of the leaves through mortar and pestle. The prepared paste was passed through muslin cloths to exclude all the plant debris and then filtered through Whatman's filter paper No.1. The filtrate was named as standard extract (S) designated as (100\%). This standard extract was diluted to $\mathrm{S} / 2, \mathrm{~S} / 10$ and $\mathrm{S} / 100$ by adding distilled water (DW). Distilled water served as control.

\section{Mortality test}

For mortality experiment, $5 \mathrm{ml}$ of water suspension containing 100 second stage juveniles (J2) of Meloidogyne incognita were transferred to $40 \mathrm{~mm}$ petridish having different concentrations $(\mathrm{S}, \mathrm{S} / 2, \mathrm{~S} / 10$ and $\mathrm{S} / 100)$ of leaf extract of different plant species separately (Alam, 1985). Each treatment contains three replicates. The petridishes were kept at $28{ }^{\circ} \mathrm{C}$ in Biological Oxygen Demand (BOD). The immobilized juveniles were counted after 24, 48 and $72 \mathrm{hrs}$ of the exposure period. The death of juveniles was confirmed by transferring immobilized juveniles into water for $1 \mathrm{~h}$ and mean percentage mortality was calculated.

\section{Hatching test}

Five fresh and uniform size eggmasses were picked from thoroughly washed roots of brinjal infected with root-knot nematode, $M$. incognita. The collected eggmasses were relocated to 40 $\mathrm{mm}$ petridishes having $5 \mathrm{ml}$ of leaf extract of different dilutions ( $\mathrm{S}, \mathrm{S} / 2, \mathrm{~S} / 10$ and $\mathrm{S} / 100$ ) separately. Each treatment has three replicates. After 6 days number of hatched juveniles was observed with the help of counting dish under stereoscopic microscope and percent inhibition over control was calculated. Distilled water served as control for hatching.

\section{Sample collection}

Ageratum conyzoides and Coccinia grandis were collected locally from the campus of Aligarh Muslim University, Aligarh for the purpose of their phytochemical analysis. Fresh and tender parts of selected plants were used for phytochemical analysis. Plant species were selected during present investigation was given in Table 01 .

\section{Preparation of plant extract}

Selected parts were picked up from the plants and then washed under running tap water to remove dust particles. The leaves, stem and fruit of plants were then air dried and crushed into powder, stored in polythene bags for use. The plant powder was transferred into test tube and required amount of distilled water was added for the soaking of powder properly. The solution was filtered through filter paper and filtered extract of the selected plant were tested further for pytochemical analysis. 
Table 01: Ethnobotanical information of selected medicinal plant species for phytochemical analysis

\begin{tabular}{llcc}
\hline \multicolumn{1}{c}{ Plants } & \multicolumn{1}{c}{ Local name } & Part used & Family \\
\hline Ageratum conyzoides & Goat weed, White weed & Leaves & Asteraceae \\
Ageratum conyzoides & Goat weed, White weed & Stem & Asteraceae \\
Coccinia grandis & Ivy gourd, Scarlet gourd & Leaves & Cuccurbitaceae \\
Coccinia grandis & Ivy gourd, Scarlet gourd & Fruit & Cuccurbitaceae \\
\hline
\end{tabular}

\section{Solvent Extraction}

$5 \mathrm{~g}$ dried powder of each plant sample were separately immersed in $50 \mathrm{ml}$ of each water, ethanol, acetone, methanol, chloroform and petroleum. The solution was kept at room temperature for $24 \mathrm{hrs}$ and filtered with Whatman's No. 1 filter paper. The filtrate was used for the phytochemical screening using the following tests.

\section{PHYTOCHEMICAL SCREENING}

\section{Test for Alkaloids (Wagner's reagent)}

A fraction of extract was taken in test tube and treated with 3-5drops of Wagner's reagent ( $1.27 \mathrm{~g}$ of iodine and $2 \mathrm{~g}$ of potassium iodide in $100 \mathrm{ml}$ of water) and examine for the formation of reddish brown precipitate (or colouration).

\section{Test for Flavonoids (Alkaline reagent test)}

$2 \mathrm{ml}$ of extracts was treated with few drops of $20 \%$ sodium hydroxide solution. Formation of intense yellow colour which becomes colourless on addition of dilute hydrochloric acid, indicates the presence of flavonoids.

\section{Test for Phenols (Ferric chloride test)}

A small amount of the extracts was treated with aqueous $5 \%$ ferric chloride and inspect for formation of deep blue or black colour.

\section{Test for Phlobatannins (Precipitate test)}

$2 \mathrm{ml}$ of extract was added with $1 \mathrm{ml}$ of $1 \%$ aqueous hydrochloric acid and then boiled formation of red precipitation represents the presence of phlobatannins.

Test for Amino acids and Proteins (1\% ninhydrin solution in acetone).

To $2 \mathrm{ml}$ of filtrate add 2-5 drops of ninhydrin solution placed in a boiling water bath for 1-2 minutes and examine for the formation of purple colour.

\section{Test for Saponins (Foam test)}

To $6 \mathrm{ml}$ of the water $2 \mathrm{ml}$ of the extract was added. The mixture was shaken vigorously and formation of persistent foam confirms the presence of saponins.

\section{Test for Tannins (Braymer's test)}

To $2 \mathrm{ml}$ of extract $10 \%$ alcoholic ferric chloride added. Formation of blue or greenish colour solution confirms the presence of Tannins.

\section{Test for Terpenoids (Salkowki's test)}

$1 \mathrm{ml}$ of chloroform was mixed to $2 \mathrm{ml}$ of each extract followed by a few drops of concentrated sulphuric acid. Reddish brown precipitate formation confirmed the presence of terpenoids.

\section{Test for steroids}

$1 \mathrm{mg}$ crude plant extracts was mixed with 10 $\mathrm{ml}$ chloroform, followed by equal volume of concentrated sulphuric acid to the test tube by sides. Conversion of upper layer into red and sulphuric acid layer represent yellow with green fluorescence confirmed the presence of steroids. 


\section{Test for Carbohydrates (Molisch's test)}

To $2 \mathrm{ml}$ of the extracts few drops of Molisch's reagent were added. This was followed by addition of $2 \mathrm{ml}$ of conc. sulfuric acid to the test tube. This mixture was then allowed to settle for two-three minutes. Presence of a red or dull violet colour at the interphase of the two layers indicates the presence of carbohydrate.

\section{Test for gum and Mucilage}

$10 \mathrm{ml}$ of distilled water was treated with the extract $(100 \mathrm{mg})$ and then $2 \mathrm{ml}$ of absolute alcohol was added with constant stirring. Formation of white or cloudy precipitate revealed the presence of gums and mucilage.

\section{Test for Glycosides}

$50 \mathrm{mg}$ of extract was hydrolyzed with concentrated hydrochloric acid for 2 hours on a water bath, filtered and the hydrolysate confirmed the presence of positive test.

\section{a. Borntrager's test}

To $3 \mathrm{ml}$ of chloroform $2 \mathrm{ml}$ of filtered hydrolysate was added and shaken, chloroform layer is separation take place followed by $10 \%$ ammonia solution. Appearance of pink colour represents the positive test.

\section{b. Legal's test}

$50 \mathrm{mg}$ of extract was mixed with pyridine then sodium nitroprusside solution was added to make alkaline using $10 \% \mathrm{NaOH}$. Formation of pink colour indicates the presence of glycoside.

\section{RESULTS}

The nematicidal effect of different parts of plants viz., stem, leaves and fruit extract is shown in table 02 and Figure 01. Among the given treatment maximum hatching of second stage juveniles (J2) was observed by Coccinia grandis leaves 18, 62, 72 and 94 followed by Coccinia grandis fruit 14, 43, 56, 81, Ageratum conyzoides stem 8, 44, 58, 64 respectively in different concentration viz., $\mathrm{S}$, $\mathrm{S} / 2, \mathrm{~S} / 10, \mathrm{~S} / 100$ and least 4, 38, 49, 52 have been showed by Ageratum conyzoides leaves in same concentration. The results indicated that leaf and stem extract of $A$. conyzoides was found to be more effective in comparison of $C$. grandis leaves extract. It showed that as dilutions increases the toxicity in response to egg inhibition decreases. The control recorded $100 \%$ egg hatchability because it contained only distilled water. Maximum hatching was observed in control (340). The percent inhibition of second stage juveniles hatching in comparison to distilled water decreased with increased in the concentration of extracts (S, S/2, S/10, and S/100). The data suggested that standard concentration of leaves extracts of $A$. conyzoides showing $98.82 \%$ inhibition of J2 hatching. Other dilutions viz., S/2, S/10 and $\mathrm{S} / 100$ were less effective as compared to standard concentration (S). It was observed that as the extract was diluted, the nematostatic and nematicidal properties of extract was decreased. The inhibition in eggs hatching of $M$. incognita generally increased with increasing in the exposure period and concentrations of extract. Distilled water (C) shows no mortality.

The result present in table 03 albic, and $d$ showed that at $24 \mathrm{hrs}$ of the exposure $A$. conyzoides leaves and stem showed pronounced mortality of $\mathrm{J} 2$ of $M$. incognita 72, 59, 50, 30 and 66, 50, 42, 27 respectively and least was observed in C. grandis 56, 40, 30, 17 in different concentration viz., S, S/2, S/10, S/100 as compare to distilled water (DW) control 0 . Mortality of Meloidogyne incognita juveniles depend upon time and concentration of the extract. The highest mortality of second stage juveniles (J2) at $48 \mathrm{hrs}$ of the exposure was depicted by the aqueous extract of $A$. conyzoides leaves $86,66,57,38$ and $A$. conyzoides stem $78,58,48,30$ and lowest percent mortality was noticed in $C$. grandis leaves 62, 44, 36, 24 in different concentration viz., S, S/2, S/10, S/100 
as compared to distilled water (DW) control 0 . A. conyzoides leaves extract showed most prominent mortality of $100,76,67,50$ followed by $A$. conyzoides stem $98,63,58,34, C$. grandis fruit 86, 63, 58, 34 and $C$. grandis leaves 68, 48, 39, 29 respectively in different concentration viz., $\mathrm{S}, \mathrm{S} / 2, \mathrm{~S} / 10, \mathrm{~S} / 100$ after 72 hours of exposure time. In all the three durations $24 \mathrm{hrs}$, $48 \mathrm{hrs}$ and $72 \mathrm{hrs}$ of the exposure time, $24 \mathrm{hrs}$ treatment showed minimum mortality while 72 hrs of the exposure showed maximum mortality. Standard (S) concentration of the extracts and $72 \mathrm{hrs}$ exposure periods represented maximum toxicity compare to all dilutions of the extract and exposure period. The mortality rate of $\mathrm{J} 2$ of $M$. incognita notably increased with the increase in concentrations of extract and the exposure time. The leaf and stem extract of $A$. conyzoides showed maximum toxicity. It was found that aqueous extract of above weeds viz., $A$. conyzoides and $C$. grandis was found to be toxic in nature in causing mortality of second stage juveniles (J2) of Meloidogyne incognita. During the experiment, the A. conyzoides leaves extract shows most prominent effect on second stage juveniles, it might be due to the presence of various types of phytoconstituents in different solvent viz., alkaloids, phenols, terpenoids, flavonoids, carbohydrate, protein etc while Coccinia grandis was found to be least effective.

Table 02: Effect of aqueous extract of fresh chopped leaves of different weeds species on the

\begin{tabular}{|c|c|c|c|c|c|c|}
\hline \multirow{2}{*}{ Treatment } & \multirow[t]{2}{*}{ Part used } & \multicolumn{5}{|c|}{ No. of juvenile hatched different concentration at 6 days } \\
\hline & & $\mathrm{S}$ & $\mathrm{S} / 2$ & $\mathrm{~S} / 10$ & $\mathrm{~S} / 100$ & DW \\
\hline Ageratum conyzoides & Leaves & $\begin{array}{c}4 \\
(98.82 \%)\end{array}$ & $\begin{array}{c}38 \\
(88.82 \%)\end{array}$ & $\begin{array}{c}49 \\
(85.58 \%)\end{array}$ & $\begin{array}{c}52 \\
(84.70 \%)\end{array}$ & $\begin{array}{l}340 \\
(0 \%)\end{array}$ \\
\hline Ageratum conyzoides & Stem & $\begin{array}{c}8 \\
(97.64 \%)\end{array}$ & $\begin{array}{c}44 \\
(87.05 \%)\end{array}$ & $\begin{array}{c}58 \\
(82.94 \%)\end{array}$ & $\begin{array}{c}64 \\
(81.17 \%)\end{array}$ & $\begin{array}{c}340 \\
(0 \%)\end{array}$ \\
\hline Coccinia grandis & Fruit & $\begin{array}{c}14 \\
(95.88 \%)\end{array}$ & $\begin{array}{c}43 \\
(87.35 \%)\end{array}$ & $\begin{array}{c}56 \\
(83.52 \%)\end{array}$ & $\begin{array}{c}81 \\
(76.17 \%)\end{array}$ & $\begin{array}{l}340 \\
(0 \%)\end{array}$ \\
\hline Coccinia grandis & Leaves & $\begin{array}{c}18 \\
(94.70 \%)\end{array}$ & $\begin{array}{c}62 \\
(81.76 \%)\end{array}$ & $\begin{array}{c}72 \\
(78.82 \%)\end{array}$ & $\begin{array}{c}94 \\
(72.35 \%)\end{array}$ & $\begin{array}{l}340 \\
(0 \%)\end{array}$ \\
\hline
\end{tabular}

Each value is an average of three replicate DW=Distilled Water (Control)

Values for percent inhibition in juvenile hatching over control are given in parentheses.

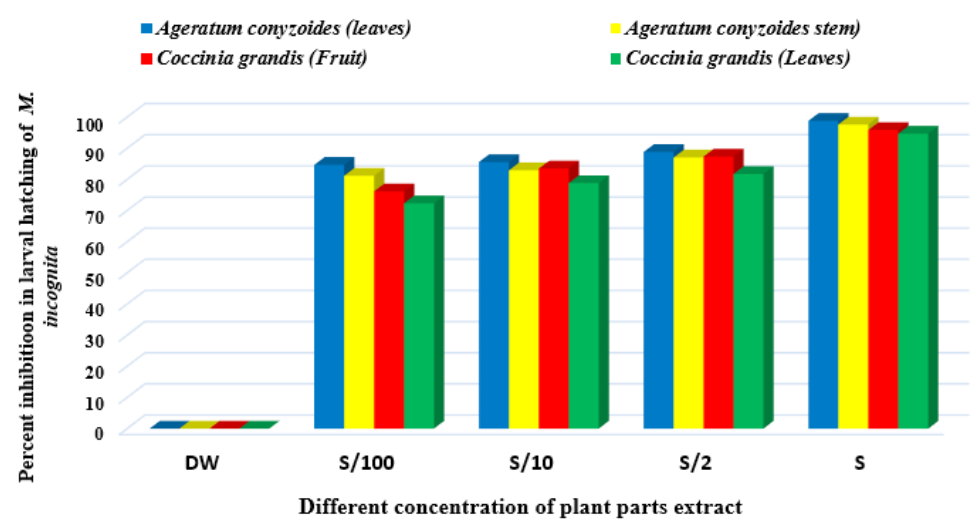

Figure 01: Percentage of inhibition of $\mathrm{J} 2$ hatching in aqueous extracts of plant species 
Table 03(a):Phytochemical analysis of Coccinia grandis fruit in various solvent of different polarity

\begin{tabular}{lcccccc}
\hline \multicolumn{1}{c}{ Phytochemicals } & Ethanol & Methane & Chloroform & Petroleum & Aqueous & Acetone \\
\hline Alkaloid & + & + & - & - & + & - \\
Flavonoid & + & + & + & - & - & - \\
Saponins & - & - & - & - & + & - \\
Carbohydrates & + & + & - & - & + & - \\
Gums/ Mucilage & + & - & - & - & - & - \\
Phenol/ Tannins & + & + & + & - & - & - \\
Terpenoids & + & + & - & + & + & + \\
Protein/ Amino & - & - & - & + & + & - \\
Steroids & - & + & - & - & + & - \\
Glycosides & + & + & - & - & + & - \\
Phlobatannins & + & - & - & - & + & - \\
\hline
\end{tabular}

$+=$ indicates presence of phytochemicals and

- = indicates absence of phytochemicals

Table 03(b): Phytochemical analysis of Coccinia grandis leaves in various solvent of different polarity

\begin{tabular}{lcccccc}
\hline \multicolumn{1}{c}{ Phytochemicals } & Petroleum & Chloroform & Ethanol & Aqueous & Methanol & Acetone \\
\hline Alkaloids & - & + & + & + & + & - \\
Saponins & - & - & + & - & - & - \\
Tannins & - & - & + & + & - & + \\
Flavonoid & - & - & - & + & + & - \\
Protein / Amino & - & + & + & + & + & - \\
Glycosides & - & + & - & + & - & + \\
Carbohydrate & - & - & + & + & + & + \\
Steroids & + & - & + & + & - & - \\
Mucilage/ Gums & - & + & - & + & - & - \\
Terpenoids & - & - & + & - & + & + \\
Phlobatannins & - & - & + & + & - & - \\
\hline
\end{tabular}

$+=$ indicates presence of phytochemicals and

- = indicates absence of phytochemicals 
Table 03 (c): Phytochemical analysis of Ageratum conyzoides leaves in various solvent of different polarity

\begin{tabular}{lcccccc}
\hline \multicolumn{1}{c}{ Phytochemicals } & Methanol & Ethanol & Water & Acetone & Chloroform & Petroleum \\
\hline Alkaloid & + & - & + & - & + & - \\
Tannins/phenol & + & - & + & + & - & - \\
Saponins & + & + & + & + & - & - \\
Glycosides & + & + & + & + & - & - \\
Flavonoids & - & + & + & + & - & - \\
Carbohydrate & + & - & + & - & - & - \\
Protein & + & + & + & - & + & - \\
Terpenoids & - & + & - & + & + & + \\
Mucilage/ gum & - & + & + & - & - & - \\
Steroids & + & - & - & + & + & - \\
Phlobatannins & + & + & + & - & - & \\
\hline \\
$+=$
\end{tabular}

Table 03(d): Phytochemical analysis of Ageratum conyzoides Stem in various solvent of different polarity

\begin{tabular}{lcccccc}
\hline \multicolumn{1}{c}{ Phytochemicals } & Methanol & Ethanol & Water & Acetone & Chloroform & Petroleum \\
\hline Alkaloid & + & + & + & + & + & - \\
Tannins/Phenol & + & + & + & - & - & - \\
Saponins & - & + & + & - & - & - \\
Glycosides & - & + & - & + & + & - \\
Flavonoids & + & + & + & + & - & - \\
Carbohydrate & + & - & - & + & + & + \\
Protein/ Amino & - & + & + & + & - & - \\
Terpenoids & + & + & + & - & - & - \\
Mucilage/ Gum & - & + & - & + & + & - \\
Steroids & + & + & + & - & - & + \\
Phlobatannins & - & - & - & + & - & - \\
\hline
\end{tabular}

$+=$ indicates presence of phytochemicals and

- = indicates absence of phytochemicals 
Table 04: Effect of water extract of chopped leaf of different plant species on the mortality of Meloidogyne incognita juveniles in vitro after 24,48 and 72 hours.

\begin{tabular}{|c|c|c|c|c|c|c|c|c|}
\hline \multirow{2}{*}{ Treatment } & \multirow{2}{*}{$\begin{array}{l}\text { Part } \\
\text { used }\end{array}$} & \multirow{2}{*}{$\begin{array}{l}\text { Duration } \\
\text { (Hrs.) }\end{array}$} & \multicolumn{5}{|c|}{ Percent mortality in different extracts } & \multirow{2}{*}{$\begin{array}{c}\text { Regression } \\
\text { Equation }\end{array}$} \\
\hline & & & S & $\mathrm{S} / 2$ & $\mathrm{~S} / 10$ & $\mathrm{~S} / 100$ & DW & \\
\hline \multirow{3}{*}{$\begin{array}{l}\text { Ageratum } \\
\text { conyzoides }\end{array}$} & \multirow{3}{*}{ Leaves } & 24 & $\begin{array}{c}72 \\
(76.8 \%)\end{array}$ & $\begin{array}{c}59 \\
(59.5 \%)\end{array}$ & $\begin{array}{c}50 \\
(42.2 \%)\end{array}$ & $\begin{array}{c}30 \\
(24.9 \%)\end{array}$ & $\begin{array}{c}0 \\
(7.6 \%)\end{array}$ & $\tilde{Y}=42.2+17.3(x-2)$ \\
\hline & & 48 & $\begin{array}{c}86 \\
(89.4 \%)\end{array}$ & $\begin{array}{c}66 \\
(69.4 \%)\end{array}$ & $\begin{array}{c}57 \\
(49.4 \%)\end{array}$ & $\begin{array}{c}38 \\
(29.4 \%)\end{array}$ & $\begin{array}{c}0 \\
(9.4 \%)\end{array}$ & $\tilde{Y}=49.4+20(x-2)$ \\
\hline & & 72 & $\begin{array}{c}100 \\
(103.8 \%)\end{array}$ & $\begin{array}{c}76 \\
(81.2 \%)\end{array}$ & $\begin{array}{c}67 \\
(58.6 \%)\end{array}$ & $\begin{array}{c}50 \\
(36 \%)\end{array}$ & $\begin{array}{c}0 \\
(13.4 \%)\end{array}$ & $\tilde{Y}=58.6+22.6(x-2)$ \\
\hline \multirow{3}{*}{$\begin{array}{l}\text { Ageratum } \\
\text { conyzoides }\end{array}$} & \multirow{3}{*}{ Stem } & 24 & $\begin{array}{c}66 \\
(68.0 \%)\end{array}$ & $\begin{array}{c}50 \\
(52.5 \%)\end{array}$ & $\begin{array}{c}42 \\
(37.0 \%)\end{array}$ & $\begin{array}{c}27 \\
(21.5 \%)\end{array}$ & $\begin{array}{c}0 \\
(6.0 \%)\end{array}$ & $\tilde{Y}=37+15.5(x-2)$ \\
\hline & & 48 & $\begin{array}{c}78 \\
(79.6 \%)\end{array}$ & $\begin{array}{c}58 \\
(61.2 \%)\end{array}$ & $\begin{array}{c}48 \\
(42.8 \%)\end{array}$ & $\begin{array}{c}30 \\
(24.4 \%)\end{array}$ & $\begin{array}{c}0 \\
(6.0 \%)\end{array}$ & $\tilde{Y}=42.8+18.4(x-2)$ \\
\hline & & 72 & $\begin{array}{c}98 \\
(95.6 \%)\end{array}$ & $\begin{array}{c}63 \\
(73.1)\end{array}$ & $\begin{array}{c}58 \\
(50.6 \%)\end{array}$ & $\begin{array}{c}34 \\
(28.1 \%)\end{array}$ & $\begin{array}{c}0 \\
(5.6 \%)\end{array}$ & $\tilde{Y}=50.6+22.5(x-2)$ \\
\hline \multirow{3}{*}{$\begin{array}{l}\text { Coccinia } \\
\text { grandis }\end{array}$} & \multirow{3}{*}{ Fruit } & 24 & $\begin{array}{c}60 \\
(61.4 \%)\end{array}$ & $\begin{array}{c}47 \\
(47.2 \%)\end{array}$ & $\begin{array}{c}33 \\
(33.0 \%)\end{array}$ & $\begin{array}{c}25 \\
(18.8 \%)\end{array}$ & $\begin{array}{c}0 \\
(4.6 \%)\end{array}$ & $\tilde{Y}=33+14.2(x-2)$ \\
\hline & & 48 & $\begin{array}{c}69 \\
(73.08 \%)\end{array}$ & $\begin{array}{c}55 \\
(56.74 \%)\end{array}$ & $\begin{array}{c}48 \\
(40.4 \%)\end{array}$ & $\begin{array}{c}30 \\
(24.06 \%)\end{array}$ & $\begin{array}{c}0 \\
(7.72 \%)\end{array}$ & $\tilde{Y}=40.4+16.34(x-2)$ \\
\hline & & 72 & $\begin{array}{c}86 \\
(90.36 \%)\end{array}$ & $\begin{array}{c}63 \\
(69.28 \%)\end{array}$ & $\begin{array}{c}58 \\
(48.2 \%)\end{array}$ & $\begin{array}{c}34 \\
(27.12 \%)\end{array}$ & $\begin{array}{c}0 \\
(6.04 \%)\end{array}$ & $\tilde{Y}=48.2+21.08(x-2)$ \\
\hline \multirow{3}{*}{$\begin{array}{l}\text { Coccinia } \\
\text { grandis }\end{array}$} & \multirow{3}{*}{ Leaves } & 24 & $\begin{array}{c}56 \\
(55.6 \%)\end{array}$ & $\begin{array}{c}40 \\
(42.1 \%)\end{array}$ & $\begin{array}{c}30 \\
(28.6 \%)\end{array}$ & $\begin{array}{c}17 \\
(15.1 \%)\end{array}$ & $\begin{array}{c}0 \\
(1.6 \%)\end{array}$ & $\tilde{Y}=28.6+13.5(x-2)$ \\
\hline & & 48 & $\begin{array}{c}62 \\
(62.0 \%)\end{array}$ & $\begin{array}{c}44 \\
(47.6 \%)\end{array}$ & $\begin{array}{c}36 \\
(33.2 \%)\end{array}$ & $\begin{array}{c}24 \\
(18.8 \%)\end{array}$ & $\begin{array}{c}0 \\
(4.4 \%)\end{array}$ & $\tilde{Y}=33.2+14.4(x-2)$ \\
\hline & & 72 & $\begin{array}{c}68 \\
(69.36 \%)\end{array}$ & $\begin{array}{c}48 \\
(53.08 \%)\end{array}$ & $\begin{array}{c}39 \\
(36.8 \%)\end{array}$ & $\begin{array}{c}29 \\
(16.52 \%)\end{array}$ & $\begin{array}{c}0 \\
(4.24 \%)\end{array}$ & $\tilde{Y}=36.8+16.28(x-2)$ \\
\hline
\end{tabular}

Each value is an average of three replicate; DW=Distilled Water (Control)

Values for percent inhibition in juvenile hatching over control are given in parentheses

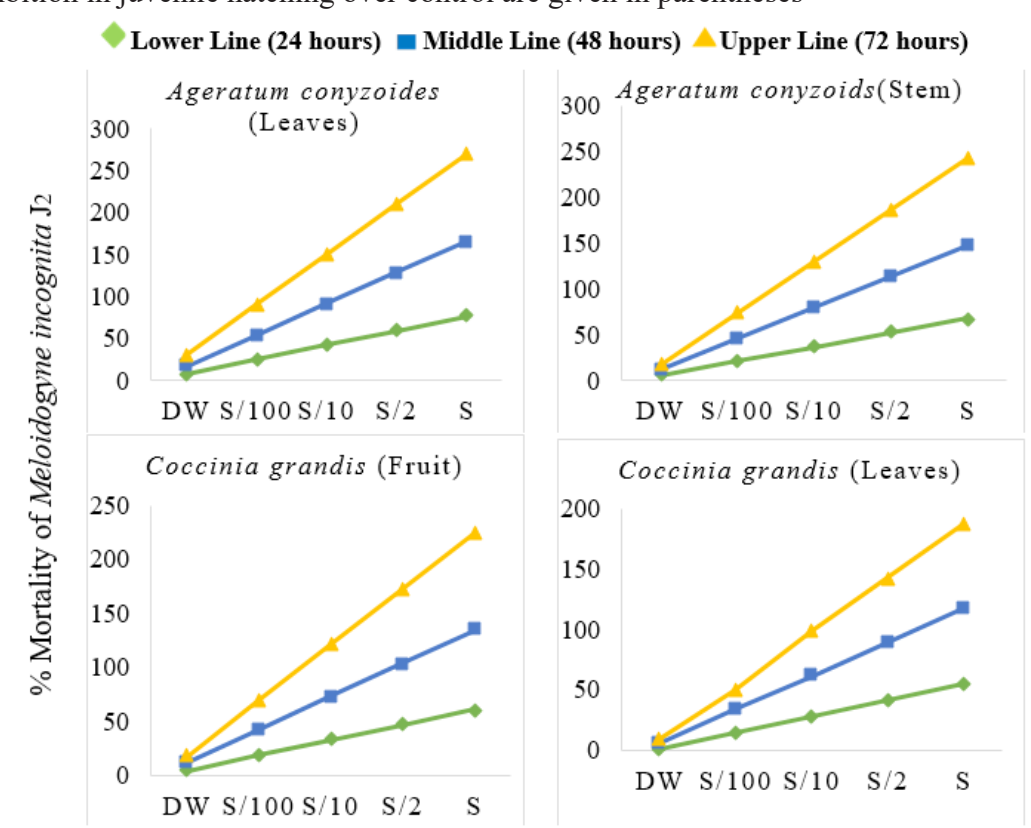

Figure 02: Regression lines showing linear relationship between different concentration of leaf extract of some plants and percent mortality of Meloidogyne incognita 


\section{DISCUSSION}

In the present study, the phytochemical analysis of the extract of $A$. conyzoides and $C$. grandis revealed the presence of alkaloids, saponins, flavonoids, phenols, tannins, steroids and glycosides. The aqueous extract of $A$. conyzoides shows marked nematostatic as well as nematicidal activity due to the presence of certain chemical constituents in the extract. Pronounced inhibition in egghatching and juvenile mortality may be possible due the presence of secondary metabolites such as phenols, alkaloids, flavonoids, phlobatannins, saponins, tannins, steroids and glycosides. The $A$. conyzoides elucidate the most negative impact against the root knot nematodes $M$. incognita causing $100 \%$ mortality after $72 \mathrm{hrs}$ of exposure time while the $C$. grandis leaves and fruit extract was found to be less inhibitory and toxic to the juveniles. A positive correlation has been setup between the juvenile's mortality, concentration of extract and the exposure time. Our results are in confirmation with Orisajo et al.,( 2007); Asif et al., (2013) and Ganai et al., (2013. Nematicidal activity of $A$. mexicana might be attributed to its contents of alkaloids (berberine, protopine, sarguinarine), amino acids, phenolics, fatty acids (myristic, palmitic, oleic, linoleic acids) and triglyceride (sn-glycerol-1-eicosa-9,12- dienoate-2palmitoleate-3-linoleate (Facchini, 2001 and Shaukat et al., 2002).

The quantity and quality of bioactive chemicals present in plant parts may vary from one part to another. Leaf extracts in the form of organic additives also released some phenolic compounds/nutrients which accelerated rapid root development and overall plant growth thus help the plants to develop resistance against nematode attack. Plants in the form of byproduct release some secondary metabolites which either enhance the plant growth or reduce the nematode infestation. These compounds are known as alkaloids, diterpenes, fatty acids, glucosinolates, isothiocyanates, phenols, polyacetlenes, sesquiterpenes and thinly (Chitwood, 2002; Bruneton, 1999; Ma et al., 1998). Lantana camara also contain pentacyclic triterpenoids described as camaric acid, lantanilic acid and olenolic acids shows nematicidal activities against $\mathrm{J}_{2}$ of $M$. incognita (Shaukat and Siddiqui, 2001). Aoudia et al. (2012) observed that phenolic compounds isolated from Melia azedarach as gallic acid, ferulic acid, $p$-hydroxybenzoic acid and caffeic acid showed toxicity against $M$. incognita. Cinnamyl acetate purified from Cinnamomum aromaticum showed $100 \%$ inhibition in M. incognita $\mathrm{J} 2$ movement after incubation for $50 \mathrm{~min}$ with $100 \mu \mathrm{g} / \mathrm{ml}$ (Nguyen et al., 2012). Abdalla et al. (2008) reported that methanol and hexane extracts depicted nematicidal property against root-knot nematode, $M$. incognita in the laboratory and also noted that extracts that contain alkaloids and flavonoids have ovicidal property against Meloidogyne eggs.

The selected plant parts are the source of the secondary metabolites viz., alkaloids, flavonoids, terpenoids, phlobatannins, mucilage, gums, protein, carbohydrate, saponins, tannins, glycosides, terpenoids, phenol and steroids. Above mentioned secondary metabolites posses nematicidal and nematostatic activity. Nematicidal properties of some phytochemicals (saponins, phlobatannins, protein, flavonoids and glycosides) content extracted by these plant leaf or oxygenated compounds that enable them to dissolve the cytoplasmic membrane of the nematode cells and their functional groups interfering with enzyme protein structures of nematodes (Trifonovo and Atanasov, 2009). Cavoski et al. (2012) reported that M. azedarach fruits containing aldehydes, carboxylic acids and alcohols were used to control M. incognita on cucumber. Phytochemical analysis also revealed that plant is rich in alkaloids, phenols, terpenoids, and flavonoids etc have high rate of nematicidal activity (Pavela, 2004). Plant material based phytochemicals are known to possess the effective control of plant-parasitic nematodes (Chitwood, 2002), including root- 
knot nematodes (Jourand et al., 2004; Hussain et al., 2011). Ranjit singh et al. (2009) found that plant extracts that contained alkaloid either singly or in combination inhibited egghatch of Meloidogyne spp. on Soybean. Pentacyclic alkaloid serpentine isolated from Catharanthus roseus root induced death and inhibited hatching of $M$. incognita at $0.2 \%$ (Chandravadana et al., 1994). The motility of $M$. incognita juveniles was also significantly reduced by exposure to eight different steroid and triterpenoid saponins from plants related to garden asparagus (Chitwood, 2002). In this investigation the extract of $A$. conyzoides and $C$. grandis having a large number of active compounds which include flavonoids, saponins, tannins, gums, glycosides, carbohydrate, steroids and alkaloids, from different plant parts like stem, leaves, and fruits, have been shown to possess nematicidal and nematostatic activity.

The present study gives assurance that aqueous extracts of $A$. conyzoides and $C$. grandis contain biological nematicidal compounds and may be used for the management of the rootknot nematode. Egg inhibition and juvenile mortality in aqueous extract in A. conyzoides was an outcome of the presence of secondary metabolites such as alkaloid, tannins, phenol, saponins, glycosides, flavonoids, carbohydrate, protein, mucilage/gum, phlobatannins in the leaves and fruits. Our results also corroborates with Asif et al, (2017), Abolusoro, (2005) and Ansari, et al., (2016). Further study is necessary to quantify and identify the phytoconstituents so that the exact mechanism can be drawn through the involvement of natural biopesticides formulation for the management of nematodes.

\section{ACKNOWLEDGEMENT}

The authors are thankful to the Chairman Department of Botany, Aligarh Muslim University, Aligarh for providing necessary facilities and DST-PURSE program for financial assistance.

\section{REFERENCES}

Abdalla, E.M., Woon, L.D., Chan, P.J., Bin, Y.H. and Yul, C.H. (2008.) Evaluation of various plant extracts for their nematicidal efficacies against juveniles of Meloidogyne incognita, J. AsiaPasific Entomology. 11: 99-102. DOI: http://dx.doi.org/10.1016/j.aspen.2008.04.004

Abolusoro, S.A. (2005). Nematicidal activities of some selected botanicals on a root-knot nematode, Meloidogyne incognita affecting tomato, Lycopersicon esculentum L. (mill) Ph.D thesis. University of Ilorin, Nigeria, AP: 2006. DOI: http://dx.doi.org/10.4314/agrosh.v7i1.39448

Afouda, L.B., Hugues \& Honorat, F. (2008) Evaluation of Amaranthus sp. and Vernonia amygdalina, and Soil amendments with Poultry Manure for the Management of Root-knot Nematodes on Eggplant. Phytoparasitica 36, 368- 376. DOI: http://dx.doi.org/10.1007/bf02980816

Adegbite, A. A. (2003). Comparative effects of carbofuran and water extract of Chromolaena odorata on growth, yield and food components of rook- knot nematode infested soybean (Glycine max (1) Merill, Ph.D thesis, University of Ibadan, Nigeria, P.120. (unpublished). DOI: http://dx.doi.org/10.3923/pjbs.2003.373.376

Ahmad, A. and Khan, A.M. (1964). Factors influencing hatching in the root-knot nematodes, Meloidogyne incognita. Indian Phytopathol. 17: 102-109. DOI: http://dx.doi.org/10.3126/ ije.v5i3.15705 
Akhtar, M. and Farzana, B. (1996): Evaluation of nematicidal properties of some members of the family Solanaceae. Biores. Technol., 57: 95-97. DOI: http://dx.doi.org/10.1016/09608524(96)00049-1

Akhtar, M. \& Alam, M.M. (1993). Utilization of waste materials in nematodes control: a review. Bioresource Tech. 45, 1-7. DOI: http://dx.doi.org/10.1016/0960-8524(93)90134-w

Alam, M.M. (1985). A simple method of in vitro screening of chemicals for nematotoxicity. Int Nematol Network Newslett. 2. 6. DOI: http://dx.doi.org/10.1016/0378-4274(85)90131-6

Al Saba, R.F., Ammi, S.N., Al Zarry \& Abdul Jawad, B. (2001) Effect of Datura stramonium extracts on root-knot nematodes M. javanica in tomato plant. Dirasat Agrl. Sci. 28, 219-226. DOI: http://dx.doi.org/10.1016/0261-2194(93)90053-1

Ansari, T., Asif, M. and Siddiqui, M.A. (2016). Potential of botanicals for root knot management on tomato. Lambert academic publishing ISBN number 9783659910920. Pp: 1-105. DOI: http://dx.doi.org/10.1007/978-3-642-23394-4_36

Asif, M., Khan, A., Tariq, M., Siddiqui, M.A. (2016). Sustainable Management of Root Knot Nematode Meloidogyne incognita through Organic Amendment on Solanum lycopersicum L. Asian Journal of biology, 1(1): 1-8. DOI: http://dx.doi.org/10.1016/s1671-2927(08)60267-9

Asif, M., Rehman, B., Parihar, K., Ganai, M.A. and Siddiqui, M.A. (2015). Effect of Various Physico-Chemical Factors on the Incidence of Root Knot Nematode Meloidogyne spp. Infesting Tomato in District Aligarh (Uttar Pradesh) India. Journal of Plant Sciences, 10(6): 234-243. DOI: http://dx.doi.org/10.3923/jps.2015.234.243

Asif, M., Parihar K., Rehman, B., Ganai, M.A., Siddiqui M.A. (2013). Bio-efficacy of some leaf extracts on the inhibition of egg hatching and mortality of Meloidogyne incognita. Arch. Phytopath. Plant Prot. 47. 1015-1021. DOI: http://dx.doi.org/10.1080/03235408.2013.829 626

Asif, M., Tariq, M., Khan, A., Rehman, B., Parihar, K., Siddiqui, M.A. (2017). Potential Role of Aqueous Extract of Some Weeds against Egg Hatching and Juvenile Mortality of Root-Knot Nematode Meloidogyne incognita. Journal of Agriculture and Crops. 3(2): 17-24. DOI: http://dx.doi.org/10.9734/ajea/2014/10525

Aoudia, H., Ntalli, N., Aissani, N., Yahiaoui-Zaidi, R. and Caboni, P. (2012). Nematotoxic phenolic compounds from Melia azedarach against Meloidogyne incognita. J Agric Food Chem. 60. 11675-11680. DOI: http://dx.doi.org/10.1021/jf3038874

Brown, P.D. and Morra, M.J. (1997). Control of soil-borne plant pests using glucosinolate containing plants. In: Advances in Agronomy. Vol. 61. (D.L. Sparks, ed.), Academic Press, San Diego, CA, USA. 167-215. DOI: http://dx.doi.org/10.1016/s0065-2113(08)60664-1

Bruneton, J. (1992). Pharmacognosy, phtochemistry, medical plants. Lavoisier Publishing, Paris, France. DOI: http://dx.doi.org/10.2307/1223435 
Cavoski, I., Chami, Z.A.I., Bouzebboudja, F., Sasanelli, N., Simeone, V., Mondelli, D., Miano, T., Sarais, G., Ntalli, N.G. and Caboni, P. (2012). Melia azedarach controls Meloidogyne incognita and triggers plant defence mechanisms on cucumber. Crop Protection. 35. 85-90. DOI: http://dx.doi.org/10.1016/j.cropro.2012.01.011

Chandravadana, M.V., Nidiry, E.S.J., Khan, R.M. and Rao, M.S. (1994). Nematicidal activity of serpentine against Meloidogyne incognita. Fundamental and Applied Nematology. 17. 18592. DOI: http://dx.doi.org/10.1163/187529286x00101

Chitwood, D.J. (2002). Phytochemical based strategies for nematode control. Annual Review of Phytopathology.40.221-9.DOI:http://dx.doi.org/10.1146/annurev.phyto.40.032602.130045

Chitwood, D. J. (2003). Research on the plant parasitic nematode biology conducted by the United States, Department of Agriculture Agricultural Research Service. Pest Manage Sci.,59:748753. DOI: http://dx.doi.org/10.1002/ps.684

Digrak, M., Alma, M.H., Licim, A. and Sen, S. (1999). Antibacterial and antifungal effects of various commercial plant extracts. Pharmaceutical Bio. 37. 216-220. DOI: http://dx.doi. org/10.1076/phbi.37.3.216.6307

Evans, W.C. (2002). Trease and Evans Pharmacognosy, $15^{\text {th }}$ edition. W.B Sauders Company Ltd, London. pp 137-139. 230-240. DOI: http://dx.doi.org/10.1016/b978-0-7020-2933-2.000022

Facchini, P. J. (2001). Alkaloid biosynthesis in plants biochemistry, cell biology, molecular regulation, and metabolic engineering applications. Ann. Rev. of Plant Physiol. and Plant Molecular Biolo. 52. 29-66. DOI: http://dx.doi.org/10.1146/annurev.arplant.52.1.29

Gabhe, S.Y., Tatke, P.A. and Khan, T.A. (2006). Evaluation of the Immunomodulatory Activity of the Methanol extract of Ficus benghalensis roots in rats. Indian J. Pharmacol. 38.271-275. DOI: http://dx.doi.org/10.4103/0253-7613.27024

Ganai, M.A., Rehman, B., Parihar, K., Asif, M. and Siddiqui, M.A. (2013). Phytotherapeutic approach for the management of Meloidogyne incognita affecting Abelmoschus esculentus (L.) Moench. Archives of Phytopathology and Plant Protection, 47:15, 1797-1805. DOI: http://dx.doi.org/10.1080/03235408.2013.858425

Goswani, B. K. and Vijayalakshmi, V. 1986. Nematicidal properties of some indigenous Plant materials against root knot nematode Meloidogyne incognita on tomato. Indian Journal of Nematology, 16 : 65-68. DOI: http://dx.doi.org/10.4314/agrosh.v7i1.39448

Hussain, M.A., Mukhtar, T. and Kayani, M.Z. (2011). Efficacy evaluation of Azadirachta indica, Calotropis procera, Datura stramonium and Tagetes erecta against root knot nematodes Meloidogyne incognita, Pak. J. Bot., 43, 197- 204. DOI: http://dx.doi.org/10.1016/j. cropro.2012.04.005

International Institute of Tropical Agriculture (2000). Evaluation of Plant- based insecticides against field and storage pests of Cowpea and Soybean, Annual Report, Plant Health Management Division. International Institute of Tropical Agriculture, pp: 33. DOI: http:// dx.doi.org/10.17660/actahortic.2000.540.2 
Jourand, P., Rapior, S., Fargette, M. and Mateille, T. (2004). Nematostatic effects of a leaf extract from Crotalaria virgulata subspgrantiana on Meloidogyne incognita and its use to protect tomato roots. Nematology, 6.765-771. DOI: http://dx.doi.org/10.1163/156854104323072955

Khan, S.A., Nazir, J., Khan, M. A., Kamran, M. and Atif, H.M. 2008. Effect of plant extracts on egg hatch and larval mortality of M. incognita. Pakistan Journal of Phytopathology, 20(2): 204-208. DOI: http://dx.doi.org/10.1007/bf03179374

Khurma, U.R. and Singh, A. (1997). Nematicidal potential of seed extracts, in vitro effects on juvenile's mortality and egg hatching of M. incognita and M. javanica. Nematol. Medit. 25: 49-54. DOI: http://dx.doi.org/10.9734/ajea/2014/10525

Lalitha, T.P, Jayanthi, P. (2012). Preliminary studies on phytochemicals and antimicrobial activity of solvent extracts of Eichhornia crassipes (Mart.) Solms. Asian Journal of Plant Science and Research. 2 (2):115-22. DOI: http://dx.doi.org/10.1007/s00436-012-3061-0

Ma, Y.T., Huang, M.C., Hsu, F.L. and Chang, H.F. (1998). Hiazinedione from Xanthium strumarium. Phytochemistry. 48. 1083-1085. DOI: http://dx.doi.org/10.1016/s0031-9422(98)00084-3

Maji, D., Roy, R.U. and Das, S. (2005). Prevention of Type 2 Diabetes in the Prediabetic Population. Journal Indian Medical Association. 103. 609-11. DOI: http://dx.doi. org/10.1002/0470857358

Moosavi, M. R. (2012). Nematicidal effect of some herbal powders and their aqueous extracts against Meloidogyne javanica. Nematrop., 42 (1): 48-56. DOI: http://dx.doi.org/10.3923/ pjbs.2001.1251.1252

Mukhtar T, Pervaz I. (2003). In vitro evaluation of ovicidal and larvicidal effects of culture filtrates of Verticillium chlamydosporium against Meloidogyne javanica. Int. J. Agri. Biol.;5: 576579. DOI: http://dx.doi.org/10.4314/ari.v6i3.55987

Mukhtar, T., Kayani, M.Z. and Hussain, M.A. (2013). Nematicidal activities of Cannabis sativa L. and Zanthoxylum alatum Roxb. Against Meloidogyne incognita. Ind Crop Prod. 42:447457. DOI: http://dx.doi.org/10.1016/j.indcrop.2012.06.027

Muniasamy, S.; Pavaraj, M. and Rajan, M. K. (2010). Efficacy of the fruit extract of Citrullus colocynthis (L.) on the root-knot nematode Meloidogyne incognita infecting Vigna ungiculata (L.). J. of Biopesticides, 3(1):309-312. DOI: http://dx.doi.org/10.5958/j.2319-1198.2.3.027

Natarajan, N., Cork, A., Boomathi, N., Pandi, R., Velavan, S. and Dhaskshanamoorthy, G. (2006). Cold aqueous extracts of African marigold, Tagetes erecta for control tomato rootknot nematode, Meloidogyne incognita. Crop Prot. 25. 1210 -1213. DOI: http://dx.doi. org/10.1016/j.cropro.2006.03.008

Nath, R.C. \& Mukherjee, B. (2000) Dioscorea floribunda, a potential source of nematicides of plant origin. Nematol. Meditt. 28, 145-149. DOI: http://dx.doi.org/10.1086/336228

Nchore, S.B., J.W. Waceke and G.M. Kariuki. (2011). Use of agro-industrial waste and organic amendments in managing root-knot nematodes in black nightshade in selected parts of Kenya. In: $10^{\text {th }}$ African Crop Science Conference Proceedings, October 10-13, 2011, Maputo, Mozambique, pp: 187-193. DOI: http://dx.doi.org/10.5402/2012/364842 
Nelaballe, V. K. and Mukkara, L. D. (2013). A Preliminary study on the nematicidal effect of some local flora on Meloidogyne incognita Chit wood infesting mulberry. Internatio. J. of Chemical, Environmental \& Biological Sci. (IJCEBS) 1(3) ISSN 2320-4079; EISSN 23204087. DOI: http://dx.doi.org/10.15192/pscp.sa.2015.10.1.4954

Nguyen, D.M.C., Seo, D.J., Kim, K.Y., Kim, T.H. and Jung, W.J. (2012). Nematode-antagonistic effects of Cinnamomum aromaticum extracts and a purified compound against Meloidogyne incognita. Nematology. 8. DOI: http://dx.doi.org/10.1163/156854112x634987

Oka,Y., Koltai, H., Bar-Eyal, M. Mor, M., Sharon, E., Chet, I. and Spiegel, Y. (2000). New strategies for the control of plant parasitic nematodes. Pest Management Science. 56.983 -988. DOI: http://dx.doi.org/10.1002/1526-4998(200011)56:11\&lt;983::aid-ps233\&gt;3.0.co;2-x

Okoko, F.J., Nwafor, O.E. and Ejechi, B.O. (1999). Growth inhibition of tomato-rot fungi by phenolic acids and essential oil extracts of pepper fruit (Denneti atripelata). Food Res Int. 32. 395-399. DOI: http://dx.doi.org/10.1016/s0963-9969(99)00057-5

Orisajo, S. B., Okeniyi, M. O., Fademi, O. A. and Dongo, L. N. (2007). Nematicidal effects of water extracts of Acalypha ciliate, Jatropha gosssypifolia, Azadiracta indica and Allium ascalonicum on Meloidogyne incognita infection on cacao seedlings. Journal of Research in Biosciences.3 (3): 49-53. DOI: http://dx.doi.org/10.4314/ijotafs.v1i1.40879

Parihar, K.; Rehman, B. and Siddiq, A. S. (2012). Impact of organic additives for sustainable management of root-knot nematode in bottle gourd. Biosciences International, 1(4): 102105. DOI: http://dx.doi.org/10.1007/s12639-013-0361-y

Pavela, R. (2004). Insecticidal activity of certain medicinal plants. Fitoterapia, 75:745-749. DOI: http://dx.doi.org/10.1016/j.fitote.2004.08.005

Pavaraj, M.,; Karthikairaj, K. and Rajan, M. K. (2010). Effect of leaf extract of Ageratum conyzoides on the biochemical profile of blackgram Vigna mungo infected by root-knot nematode, Meloidogyne incognita. J. of Biopesticides, 3(1): 313-316. DOI: http://dx.doi. $\operatorname{org} / 10.5958 / \mathrm{j} .2319-1198.2 .3 .027$

Premanathan, M., Rajendran, S., Ramanathan, T., Kathiresan, K., Nakashima, H. and Yamamato, N. (2000).A Survey of Some Indian Medicinal Plants for Anti-Human Immune deficiency Virus (HIV) Activity. Indian J. Med. Res.112: 73-77. DOI: http://dx.doi. org/10.3109/13880209509088153

Ranjit singh, K. N. and Sucheta, K.R. (2009). Effect of root extracts to control root knot nematode (Meloidogyne spp.) of Soybean (Glycine max). Biological Forum- An International Journal. 1. 65- 68. DOI: http://dx.doi.org/10.17660/actahortic.2012.933.51

Ravichandra, N.G. (2008). Plant Nematology. L K International Publishing House, New Delhi 110016. Pp. 18. DOI: http://dx.doi.org/10.1007/978-81-322-1841-8

Sano, Z. (2005), Cultural control of the nematode damage. In: Large encyclopedia of environmental conservation agriculture, ed. Noubunkyo. Noubunkyo, Tokyo, pp. 281316. DOI: http:// dx.doi.org/10.1177/147447400501200114 
Shaukat, S.S. and Siddiqui, I.A. (2001). Lantana camara in the soil changes the fungal community structure and reduces impact of Meloidogyne javanica on Mungbean. Phytopathologia Mediterranea. 40. 245-252. DOI: http://dx.doi.org/10.5586/aa.2002.050

Shaukat, S.S., Siddiqui, I.A., Khan, G.H. and Zaki, M.J. (2002). Nematicidal and allelopathic potential of Argemone mexicana, a tropical annual weed. Plant and Soil, 245: 239-447. DOI: http://dx.doi.org/10.1023/a:1020476024966

Sitaramaiah, K. and Singh, R.S. (1978a). Effect of organic amendment on phenolic contents of soil and plants and response of Meloidogyne javanica and its hosts to related compounds. Plant Soil. 50. 671-679. DOI: http://dx.doi.org/10.1007/bf02107218

Tiyagi, S.A., Mahmood, I. and Rizvi, R. (2009a) Application of some latex bearing plants for the management of phytonematodes infecting tomato and eggplant. Thai J. Agrl. Sci. 42, 183-189. DOI: http://dx.doi.org/10.1007/978-3-642-23394-4_36

Trifonovo, Z. and Atanasov, A. (2009). Investigation on the nematicidal effects of some plant extracts on mortality and hatching of Meloidogyne incognita and Globodera rostochiensis, Plant Science. 46. 548-554. DOI: http://dx.doi.org/10.9734/ajea/2014/10525

Turner, C.E., Elsohly, M.A. and Boeren, E.G. (1980). Constituents of Cannabis sativa L. XVII. A review of the natural constituents. J. Nat. Prod. 43:169-234. DOI: http://dx.doi.org/10.1021/ np50008a001

Ujvary, I. (2002). Transforming natural products into natural pesticides-experience and expectations. Phytoparasitica. 30. 439-442. DOI: http://dx.doi.org/10.1007/bf02979747 